Studia z Dziejów Średniowiecza, t. 23, 2019

\author{
Adam Kromer \\ (Instytut Historii, Uniwersytet Gdański)
}

\title{
„Oliwa” - pochodzenie nazwy podgdańskiego klasztoru cystersów. Przyczynek do badań
}

https://doi.org/10.26881/sds.2019.23.05

Keywords: Oliwa, monastery, abbey, etymology, name, Cistercians

\section{Wstęp}

Przez ponad sześć wieków Oliwa - mała klasztorna wioska - nie prowadziła samodzielnego bytu, pozostając własnością klasztoru, a jej nazwa odnosiła się przede wszystkim do cysterskiego klasztoru i opactwa. Wieś zaczęła funkcjonować jako niezależna miejscowość dopiero po pierwszym rozbiorze Polski, gdy władze pruskie skonfiskowały majątek klasztoru, a potem, w 1831 r., dokonały ostatecznej sekularyzacji opactwa. Chyba od tego momentu można mówić o oderwaniu nazwy „Oliwa” od klasztoru. Jednak nawet w połowie XIX w., gdy powołano do istnienia gminę wiejską Oliwa (Landgemeinde Oliva) i jeszcze później, gdy Oliwa stała się uzdrowiskiem, jej sercem pozostał dawny klasztor cysterski. Nie przypadkiem Stanisław Tarnowski (1837-1917) - dwukrotny rektor Uniwersytetu Jagiellońskiego - pod koniec XIX w. napisał we wspomnieniach z odwiedzin w Prusach Królewskich: ,idźmy do tego co ciekawsze, co jest dopiero naprawdę Oliwa, do kościoła"1.

Nazwa „Oliwa” pojawia się w dokumentach związanych z powstaniem i najstarszymi dziejami cysterskiego klasztoru. Obecnie przyjmuje się, że objęcie klasztoru przez przybyły z macierzystego Kołbacza nowy konwent miało miejsce 2 lipca $1186 \mathrm{r}$. Taka datę wymienia dokument Mściwoja II z 1277 r. ${ }^{2}$ Tymczasem na dokumencie fundacyjnym

1 S. Tarnowski, Z wakacyj. (Prusy Królewskie), t. 2, Kraków 1894, s. 241.

$2 \mathrm{P}, \mathrm{nr} 289$. 
wystawionym dla klasztoru oliwskiego przez władającego ziemia gdańską Sambora widnieje inna data - 1178 r. Zachowany dokument nie jest oryginalnym dyplomem, ale kopią utworzoną w pierwszej połowie XIII w. Rozbieżność datacji próbowano wytłumaczyć, przesuwając datę wystawienia oryginalnego niezachowanego dokumentu na 1188 r. (data 1178 na kopii miałaby powstać w wyniku błędu kopisty) lub uznając, że dokument Sambora powstał po objęciu klasztoru przez konwent (w 1186 r.) ze wsteczna data (1178 r.). To celowe antydatowanie zostało potem powtórzone w trzynastowiecznej kopii ${ }^{3}$. Możliwe, że istnieje jeszcze inne rozwiązanie. Skoro fundacja klasztoru to proces rozciagnięty w czasie i składający się z kilku etapów ${ }^{4}$, to czy dokument mógł zostać wydany na początku tego procesu - kilka lat przed przybyciem konwentu? Chronologia fundacji klasztoru oliwskiego nadal pozostaje otwarta i wymaga dalszych badań.

W dokumencie fundacyjnym klasztoru Oliwa pojawia się obok sześciu innych osad stanowiących zalążek majątku opactwa. Na tle słowiańskich nazw tych miejscowości (pomimo zniekształconego zapisu) ${ }^{5}$ wyróżnia się nietypowym brzmieniem. Bodaj wszyscy badacze zgadzają się, że nie jest to nazwa istniejąca przed założeniem klasztoru, lecz nowa - nadana przez cysterskich zakonników. Rozbieżności pojawiają się dopiero podczas prób wyjaśnienia, dlaczego cystersi wybrali taka, a nie inną nazwę dla swojej nowej siedziby, oraz jakie niosła treści i z czym się kojarzyła.

3 O dokumencie fundacyjnym zob.: G. Labuda, Ze studiów nad najstarszymi dokumentami Pomorza Gdańskiego, ZH 1953, t. 18, s. 122-130; J. Spors, Dokument fundacyjny Sambora I dla Oliwy z roku 1178, SŹ 1977, t. 22, s. 111-124; K. Bruski, Sprawa autentyczności dokumentów Sambora II dla cystersów oliwskich, „Zeszyty Naukowe Wydziału Humanistycznego Uniwersytetu Gdańskiego. Historia” 1985, nr 15 , s. 5-20.

4 Por. J. Zawadzka, Proces fundowania opactw cysterskich $w$ XII $i$ XIII wieku, Rocz. Hum. 1958, t. 7/2, s. 121-150; K. Morajko, Poczatki fundacji klasztoru cystersów w Szczyrzycu, Kraków 2008, s. 13-22.

5 Pozostałe miejscowości podarowane w XII w. klasztorowi to (w brzmieniu z dokumentu): „Gransowi, Sincimitz, Salcowitz, Clembowi, Sterkow, Stanowe”. Z tych zachowały się nazwy Gręzowo (tu: „Gransowi”, niem. Grenzlau, obecnie także: Leśna Polana) oraz Stawowie (tu: „Stanowe”, niem. Hochwasser) znajdujące się w obecnych granicach Sopotu. Pozostałe położone bliżej Oliwy zaginęły (Clembowi wspominane jeszcze w 1279 r. jako część folwarku klasztornego); por. Kronika oliwska. Źródto do dziejów Pomorza Wschodniego z połowy XIV wieku, tłum. D. Pietkiewicz, wstęp i komentarz B. Śliwiński, Malbork 2008, s. 48. 


\section{Oliwa jako łacińska nazwa alegoryczna}

1.

W czasach, gdy łacina była powszechnie stosowana, nazwę „Oliwa” (,Oliva”) rozumiano w duchu tego języka jako „oliwka” - drzewo oliwne.

Wizerunki oliwnego drzewa zajmują ważne miejsce w wystroju dawnego klasztoru i potwierdzaja, że cystersi łączyli jego nazwę z tym symbolem. Niestety, nie wiemy, jak dokładnie wyglądał wystrój oliwskiej świątyni przed jej niemal doszczętnym zniszczeniem, którego w 1577 r. dokonali gdańscy żołnierze. Można przypuszczać, że przedstawienia drzewa oliwnego i gałązek oliwnych nie pojawiły się w przestrzeni klasztoru dopiero po podniesieniu z ruin, ale nawiązywały do wcześniejszego wystroju. Jednak nie ma na to materialnych dowodów i dopóki takie się nie pojawia, jesteśmy zmuszeni opierać się na innych przesłankach.

Wiadomo, że cystersi źródła symbolu drzewa oliwnego upatrywali w konkretnym fragmencie Biblii. Ten pojawiajacy się na klasztornych malowidłach biblijny passus przywołuje pochodzaca z pierwszej połowy XVII w. relacja dyplomaty francuskiego Charlesa Ogiera. Jako sekretarz ambasadora Claude'a de Mesmes, hrabiego d'Avaux, uczestniczył on w podróży dyplomatycznej do Polski w latach 1635-1636. W swoich dziennikach podróży, pod datą 22 maja $1636 \mathrm{r}$., zdał relację z wizyty w opactwie oliwskim. Przedstawił zasłyszaną od zakonników opowieść o fundatorze klasztoru - księciu Sobiesławie, który we śnie zobaczył werset psalmu: „quasi oliva fructifera in domo Domini” (,niczym owocujace drzewko oliwne w domu Pana") ${ }^{6}$. Za poradą kapelana ufundował klasztor, któremu nadał nazwę Oliva - w nawiązaniu

6 Ps 52(51),10. W Kościele powszechnie było używane łacińskie tłumaczenie Biblii opracowane przez Hieronima ze Strydonu, znane jako Wulgata. W średniowieczu próbowano zrewidować i ujednolić coraz bardziej skażony tekst Wulgaty. Dopiero jednak po uznaniu jej przez Sobór Trydencki za oficjalne tłumaczenie Biblii powstała jednolita wersja znana jako Vulgata Clementina (promulgowana w 1598 r.). W tej wersji tłumaczenia werset cytowanego psalmu brzmi: „Ego autem sicut virens oliva in domo Dei”. Psalm ten według podziału przejętego z greckiej Septuaginty był opatrzony numerem 51. W najnowszych tłumaczeniach Biblii na języki narodowe, a także w najnowszym opracowaniu oficjalnego łacińskiego tłumaczenia (Nova Vulgata - promulgowana w 1979 r.) numeracja psalmów została oparta na hebrajskich tekstach masoreckich. Cytowany psalm uzyskał inny numer 52. Stąd podwójna numeracja w siglach biblijnych. 
do wyśnionego cytatu 7 . Rzecz jasna - to tylko legenda, ale powstała ze złożenia przekazanych przez tradycję klasztorną informacji o fundacji klasztoru oraz o związku nazwy klasztoru z cytatem biblijnym. Nadal jednak mowa o tradycji klasztornej odległej o całe stulecia od czasu fundacji.

Chcąc zrozumieć powód, dla którego mieliby cystersi nazwać nowy klasztor drzewem oliwnym, trzeba wgłębić się w treść, jaką niesie ów symbol, albo ściślej - jaką treścią wypełniali symbol mnisi zakonu cysterskiego pod koniec XII w. Może właśnie zagubienie tego kulturowego kontekstu sprawiło, że część badaczy poszukiwała odmiennej niż alegoryczna etymologii nazwy „Oliwa”.

2.

Dziewiętnastowieczni autorzy, piszący o Oliwie już po sekularyzacji klasztoru (1831 r.), nazwę opactwa i przyklasztornej wioski nadal interpretowali jako nazwę symboliczną nadaną przez cysterskich mnichów.

W duchu etymologii klasztornej nazwę „Oliwa” z symbolem drzewa oliwnego wiazał Theodor Hirsch (1806-1881) - autor monografii opactwa oliwskiego z 1850 r. ${ }^{8}$ Podobnie uczynił w 1868 r. Franz Winter (1833-1878) w opracowaniu dotyczącym cystersów ${ }^{9}$ oraz w 1885 r. Josef Nikodem Pawlowski (1816-1902) w pracy popularyzującej historię i kulturę gdańskiego regionu ${ }^{10}$.

Inaczej pochodzenia nazwy „Oliwa” szukał Gotthilf Löschin (1790-1868). Wywodził ja - owszem, ze świata symboliki biblijnej - ale nie od drzewa, lecz od Góry Oliwnej. Taką etymologię przedstawił w $1832 \mathrm{r}^{11}$ Wtedy jeszcze skłaniał się ku etymologii „tradycyjnej” i na jej potwierdzenie przywoływał przedstawienia oliwki licznie występujące w klasztorze. Etymologię wiążącą nazwę

7 K. Ogier, Dziennik podróży do Polski 1635-1636, cz. 2, tłum. E. Jędrkiewicz, wstęp i objaśnienia W. Czapliński, Gdańsk 1953, s. 164-167.

8 Th. Hirsch, Das Kloster Oliva. Ein Beitrag zur Geschichte der Westpreußischen Kunstbauten, Danzig 1850, s. 6.

9 F. Winter, Die Cistercienser des nordöstlichen Deutschlands. Ein Beitrag zur Kirchen- und Culturgeschichte des deutschen Mittelalters, Gotha 1868, s. 136.

10 J.N. Pawlowski, Populäre Geschichte und Beschreibung des Danziger Landkreis mit einem Anhange: Culturhistorische, meteorologische und andere Notizen in chronologischer Folge, Danzig 1885, s. 30.

11 G. Löschin, Oliva [w:] Allgemeine Encyklopädie der Wissenschaften und Künste in alphabetischen Folge von genannten Schriftstellern bearbeitet und herausgegeben von J.S. Ersch und J.S. Gruber mit Kupfern und Charten, Th. 3, Leipzig 1832, s. 485. 
Oliwy z Góra Oliwną odnotował jako podawana przez samych zakonników. Zastrzegał jednak, że mnisi mają wiele bajecznych rzeczy do opowiedzenia o swoim klasztorze (,viel Fabelhaftes von ihrem Kloster zu erzählen wussten") ${ }^{12}$.

Trudno orzec, czy Löschin znalazł tę etymologię w jakichś źródłach cysterskich (żadnych nie wskazał), czy usłyszał bezpośrednio od oliwskich zakonników w schyłkowym okresie istnienia klasztoru. Cystersów w konwencie oliwskim było wtedy zaledwie kilku, a i tak część pełniła posługę w parafiach poza Oliwą. W chwili kasaty klasztoru (1831 r.), a zatem tuż przed wydaniem pracy Löschina, w Oliwie było już tylko pięciu cystersów (czterech ojców i jeden konwers) ${ }^{13}$. Trudno orzec, na ile miarodajne były przekazy ostatnich mnichów, w które zresztą sam Löschin powątpiewał.

Najwyraźniej ostatecznie jednak odrzucił tradycyjną etymologię, ponieważ już w kolejnym opracowaniu z $1836 \mathrm{r}$. wymienia wyłącznie Górę Oliwną (Mons Olivarum) jako źródło nazwy opactwa, od którego z kolei powstała nazwa klasztornej wsi ${ }^{14}$. Pewnie za Löschinem nazwę opactwa od Góry Oliwnej wywodzili Johann Karl Kretzschmer, w monografii wydanej w $1847 \mathrm{r}^{15}$, oraz Franz Brandstätter w przewodniku z 1855 r. ${ }^{16}$ Według tych autorów nazwa Oliwa miałaby być skrótem określenia: klasztor „ad Montem Olivarum” (pod Góra Oliwna). Zakonnicy cysterscy mieliby z biblijną Górą Oliwną skojarzyć wzniesienie, u którego stóp pobudowali klasztor - czyli wzgórze Pachołek, noszace w XIX i pierwszej połowie XX w. nazwę Karlsberg ${ }^{17}$.

Popularność tych opracowań wpłynęła na opinię kolejnych autorów piszących o Oliwie. Informator wydany z okazji 38. zjazdu katolików

12 Ibidem.

13 Por. S. Kościelak, Skład konwentu cystersów $w$ Oliwie $w$ świetle raportów dla Ministerstwa Wyznań w Berlinie z lat 1817-1826, „Miesięcznik Archidiecezji Gdańskiej” 2008, t. 52, s. 199-210.

14 G. Löschin, Danzig und seine Umgebungen, Danzig 1836, s. 211. Autor powtarzał teorię i w następnych wydaniach swojej pracy, zob. Danzig und seine Umgebungen, Dritte, aufs neue vermehrte und verbesserte Auflage, Danzig 1853, s. 181-182.

15 J.K. Kretzschmer, Geschichte und Beschreibung der Klöster in Pommerellen. Erstes Heft. Die Cisterzienser-Abtei Oliva, Danzig 1847, s. 27.

16 F. Brandstätter, Die Weichsel. Historisch, topographisch, malerisch unter Mitwirkung einer Anzahl von kundigen Männern beschrieben, Marienwerder 1855, s. 159.

17 Tu jednak trzeba nadmienić, że według samego Löschina nazwa wzgórza Pachołek (Pacholkenberg) to raczej pierwotnie Picollenberg - nazwa upamiętniająca staropruskiego boga Picollosa. Mieli tak sądzić badacze starożytności, ale Löschin nie wskazał żadnego i wydaje się, że owa etymologia była jego własną inwencja, zob. G. Löschin, Danzig und seine Umgebungen, Danzig 1853, s. 181. 
niemieckich w Gdańsku wprost przywołuje Löschina i jego teorię na temat pochodzenia nazwy „Oliwa” od Góry Oliwnej ${ }^{18}$. Podobnie autor artykułu w tygodniku diecezji chełmińskiej w 1871 r. pisze, że Oliwa nazwę swą wzięła od Góry Oliwnej i klasztor nazywał się też klasztorem pod Górą Oliwna, a pospolicie w skróceniu tylko Oliwa"19. Mimo pewnej popularności teoria Löschina nie zastapiła tradycyjnej etymologii, a kolejni autorzy wracają raczej do etymologii tradycyjnej. Co więcej, próbują wyjaśniać, dlaczego źródłem nazwy „Oliwa” miałby być symbol drzewa czy gałązi oliwnej.

Johannes Heise, w opracowanym na potrzeby serii wydawniczej poświęconej sztuce i architekturze Prus Zachodnich, w artykule o Oliwie (1885 r.) przypuszczał, że nazwa „Oliva” mogła zostać nadana przez mnichów w nawiązaniu do położenia klasztoru w odosobnionej, spokojnej okolicy, co mieliby zakonnicy skojarzyć z symbolem pokoju - gałązką oliwną ${ }^{20}$. Wydaje się, że Heise poszukał skojarzenia nazwy klasztoru z symbolem drzewa oliwnego w zbyt zawiły sposób. Inni autorzy szukali bardziej bezpośrednich powiązań. Podręczna encyklopedya kjościelna (1904-1914) podawała: „nazwę wzięło opactwo od gałązi oliwnej, która zakonnicy odrysowali na szczycie swej kaplicy, jako symbol pokojowej pracy" ${ }^{21}$. Wiktor Radzyński w przewodniku z 1892 r. pisał natomiast: „Syn Sobiesława, Sambor I, [...] nazwał klasztor Oliwa, ponieważ tenże miał być podobnym do drzewa oliwnego, obfitujacego w owoce" ${ }^{22}$. Hermann Mankowski, autor wydanego w 1923 r. przewodnika po Oliwie, stwierdził jednoznacznie, że pochodzenie i znaczenie nazwy „Oliwa” ma związek wyłącznie z drzewkiem oliwnym, ewentualnie owocami oliwki, a nie z Góra Oliwna, o czym świadczą nowe badania ${ }^{23}$. Erich Keyser w 1926 r. wprost odrzuca jako nieuzasadnioną teorię Löschina o powiązaniu nazwy klasztoru z Górą Oliwną, wskazując na drzewo oliwne - symbol

18 Por. Danzig, Festschrift zur General-Versammlung der Katholiken Deutschlands in Danzig vom 30. August bis 3. September 1891, Danzig 1891, s. 138.

19 Klasztor Cystersów w Oliwie, „Pielgrzym, pismo religijne dla ludu” 1871, R. 3, nr 51 (21.12.1871), s. 405.

20 Die Bau und Kunstdenkmäler des Landkreises Danzig (Die Bau- und Kunstdenkmäler der Provinz Westpreussen. Heft II, Der Landkreis Danzig), Danzig 1885, s. 96.

21 Podręczna encyklopedya kościelna, t. 29-30, oprac. S. Gall et al., red. Z. Chełmicki, Kraków 1913, s. 13.

22 W. Radzyński, Przewodnik po Copotach, Gdańsku i okolicy poprzedzony krótkim rysem dziejów okolicznego wybrzeża, Gdańsk 1892, s. 20-21.

23 H. Mankowski, Führer durch die Cistercienserkirche und das Cistercienserkloster sowie die nächste Umgebung von Oliva, Oliva 1923, s. 5. 
pokoju - jako źródło nazwy ${ }^{24}$. Po II wojnie światowej kanclerz gdańskiej kurii Kazimierz Mirynowski w swoim informatorze o katedrze oliwskiej podaje trzy wersje pochodzenia nazwy „Oliwa”, nie faworyzując żadnej z nich. Wszystkie odwołują się do symbolu gałązki oliwnej: „l-o przybycie mnichów, jako zwiastunów pokoju. Symbolem pokoju jest gałąka oliwna, 2-o zakonnicy mieli wymalować nad wejściem do swej pierwotnej drewnianej kapliczki gałązkę oliwna, 3-o książę pomorski Subisław miał ujrzeć we śnie anioła w koronie z lilii i z gałązką oliwną w ręce, który żądał, by książę chrzest przyjął, Subisław się ochrzcił" 25 . Czy wreszcie Gerard Labuda, który też opowiedział się za drzewem oliwnym: „alegoryczna nazwa: «Oliwa» wywiedziona niewątpliwie z drzewa oliwkowego, mającego symbolizować pokojowe kwitnięcie nowego klasztoru" ${ }^{26}$.

\section{Polska teoria hydronimiczna}

1 .

We wszystkich wyżej wymienionych teoriach nazwa „Oliwa”, niezależnie, od jakiego symbolu wywodzona, jest traktowana jako alegoria.

W XX w. w literaturze polskiej pojawiła się nowa hipoteza odrzucająca alegoryczność nazwy. Nazwa „Oliwa” miałaby być zniekształceniem zastanej przez cystersów słowiańskiej nazwy upodobnionej przez skojarzenie fonetyczne z Górą Oliwną. Przedstawił taką hipotezę Józef Staszewski (jeszcze pod nazwiskiem Józef Haliczer) w swoim Stowniku geograficznym z 1933 r., gdzie o Oliwie napisał, że ,jest to n[azwa] rzeczna, podobnie Olawa (p.), którą Cystersi przyjęli jako aluzję do Góry Oliwnej z Pisma Św[iętego]"27. Krótkie hasło słownikowe zostało tylko nieznacznie poszerzone w kolejnych wydaniach pracy $^{28}$. Staszewski podtrzymał teorię, że nazwa Oliwa miałaby być zniekształceniem dawniejszej słowiańskiej nazwy: „pierwowzorem

24 E. Keyser, Olivaer Studien, „Zeitschrift des Westpreussischen Geschichtsverein" 1926, H. 66, s. 73.

25 K. Mirynowski, Katedra w Oliwie, Gdańsk 1949, s. 1.

26 G. Labuda, Ze studiów nad najstarszymi dokumentami Pomorza Gdańskiego, ZH 1952, t. 18, s. 130.

27 J. Haliczer, Stownik geograficzny. Pochodzenie $i$ znaczenie nazw geograficznych, Tarnopol 1933, s. 113. We wskazanym przez autora odwołaniu do hasła „Olawa” widnieje tylko informacja, iż jest to nazwa rzeczna.

28 J. Staszewski, Stownik geograficzny. Pochodzenie $i$ znaczenie nazw geograficznych, Gdynia 1948, s. 225; idem, Stownik geograficzny. Pochodzenie i znaczenie nazw 
jest przypuszczalnie n[azwa] rzeczna gniazda «Olawa», którą cystersi upodobnili «ad Montem Olivarum» - do góry Oliwnej”"29. Jednak sam zauważał, że istnienia nazwy „*Olawa” nie da się potwierdzić żadnymi źródłami pisanymi i właściwie nie podał żadnych argumentów na poparcie swojej teorii ${ }^{30}$.

Hipotezę przyjęli i rozwinęli Zygmunt Brocki i Hubert Górnowicz. Pierwsza z prac tych autorów zajmująca się etymologią Oliwy to artykuł z 1967 r. ${ }^{31}$, w którym Brocki domyśla się, że dzisiejszy Potok Oliwski nosił pierwotnie nazwe „*Oława” (autor przywołuje przykłady podobnych nazw słowiańskich). Od strugi miałaby zostać nazwana - tym samym mianem „ "Oława” - mała osada, w której cystersi założyli klasztor. Dalej - jak wcześniej Staszewski - sądzi, że cystersi upodobnili zastaną nazwę „*Oława” do Góry Oliwnej, z którą miało im się skojarzyć wzgórze Pachołek. Pomysł o tyle różni się od wspominanej wyżej hipotezy Löschina, że tu skojarzenie cystersów miałoby się pojawić dopiero po zetknięciu z nazwą „ ${ }^{*}$ Oława”.

Hipotetyczną nazwę potoku „ "Oława” Brocki wywodzi z formantu olz, majacego oznaczać rodzaj piwa i tłumaczy to kolorem wody w rzeczce, sugerując, że nazwa miała charakter żartobliwy ${ }^{32}$. Problematyczny brak nazwy „ ${ }^{*}$ Oława” w dyplomie fundacyjnym tłumaczy autor tym, że zachowany do naszych czasów dokument nie jest oryginałem wystawionym przez Sambora, ale pochodzaca z około 1230 r. kopia. Przypuszcza zatem, że w oryginale mogła znajdować się odmienna nazwa: „Może [...] nazwa wsi zapisana była w formie "*Olava»: taka łacińska forma odpowiadałaby przecież właśnie fonetycznie słowiańskiej nazwie "*Oława»"33. Natomiast wywodzenie nazwy klasztoru od drzewa oliwnego uznaje Brocki za etymologię ludowa ${ }^{34}$ czy też pseudoetymologię ${ }^{35}$.

Na wspomnianym artykule został oparty poświęcony Oliwie podrozdział książki Nazwy miast Pomorza Gdańskiego ${ }^{36}$ wydanej pod redakcją Zygmunta Brockiego i Huberta Górnowicza. Autorzy powtarzają

geograficznych, Warszawa 1959, s. 215; idem, Mały słownik. Pochodzenie $i$ znaczenie nazw geograficznych, Warszawa 1968, s. 318.

29 J. Staszewski, Maty słownik..., s. 318.

30 Ibidem.

31 O nazwach dwóch gdańskich potoków, „Ziemia” 1967, s. 211-214.

32 Ibidem, s. 212.

33 Ibidem, s. 213.

34 Ibidem.

35 Ibidem, s. 214.

36 Nazwy miast Pomorza Gdańskiego, red. H. Górnowicz, Z. Brocki, Wrocław 1978 , s. $45-47$. 
tu hipotezę o zniekształceniu przez cystersów zastanej nazwy słowiańskiej: „Nazwa Oliwa jest odosobniona. Powszechnie się sądzi, że nazwę nadali cystersi dla uczczenia Góry Oliwnej (łac. Mons Olivarum) w Jerozolimie. Jednak cystersi nigdy nie mieli nic wspólnego z Góra Oliwną w Jerozolimie. Stąd należy przypuszczać, że dzisiejsza postać tej nazwy jest wtórna. Miejsce, na którym cystersi założyli klasztor, musiało przecież mieć jakaś nazwę słowiańska, którą cystersi tylko upodobnili do (Mons) Olivarum" ${ }^{37}$. Dalej następuje rekonstrukcja nazwy rzecznej „*Oława” i jej etymologia. Próbujac wytłumaczyć brak takiej formy w źródłach, autorzy powtarzają wcześniejsze przypuszczenie, że skoro nie znamy oryginału dyplomu, to „kto wie, czy nie było w nim nazwy "*Oława», tj. - w pisowni łacińskiej - «*Olava»"38.

Pewnego rodzaju streszczenie hipotezy Brockiego i Górnowicza znalazło się na kartach pierwszego tomu Historii Gdańska pod redakcją Edmunda Cieślaka. Górnowicz część zamieszczonego tam artykułu zatytułowanego Nazwy Gdańska i jego dzielnic poświęcił Oliwie $^{39}$. W zasadzie powtórzył wcześniejszą hipotezę Brockiego. Założył, że osada, w której cystersi zbudowali klasztor, musiała mieć pierwotną nazwę słowiańska, zniekształconą przez cystersów do formy „Oliva”: „Oliwa” jest fonetycznie zniemczoną nazwą polska, którą rekonstruujemy na podstawie porównawczych faktów śląskich jako „*Oława” ${ }^{* 0}$. Etymologie odwołujacce się do symbolu drzewka lub gałąki oliwnej uznał za nienaukowe ${ }^{41}$.

Rozszerzoną wersję hipotezy przedstawił Brocki w artykule Nazwy rzeczne Gdańska-Oliwy i nazwa miejscowa Oliwa ${ }^{42}$. Również tutaj pojawiają się wcześniejsze przypuszczenia, ,że Oliwa jest przekształceniem nazwy miejscowej “*Oława»"43, jak też, że „w oryginale [dokumentu fundacyjnego] nazwa wsi mogła być zapisana w postaci «*Olava», «*Olaua» czy «*Olawa»"44, a w kopii z około 1230 r. - już w utrwalonej wersji „Olyva”. Oprócz powtórzenia argumentów znanych z wcześniej-

37 Ibidem, s. 46.

38 Ibidem, s. 47.

39 H. Górnowicz, Nazwy Gdańska i jego dzielnic [w:] Historia Gdańska, t. 1: Do roku 1454, red. E. Cieślak, J. Rumiński, Gdańsk 1978, s. 15-26 (tam o Oliwie: s. 18-19).

$40 \quad$ Ibidem, s. 19.

41 Ibidem.

42 Z. Brocki, Nazwy rzeczne Gdańska-Oliwy i nazwa miejscowa Oliwa, „Rocznik Gdański” 1979, t. 39, s. 157-177.

43 Ibidem, s. 161.

$44 \quad$ Ibidem, s. 162 
szych prac Brocki rozwiną rozważania etymologiczne dotyczace nazwy „ Oława”. Niezmiennie miałaby to być pierwotnie nazwa potoku przeniesiona na wioskę, ale tym razem Brocki dodaje, że wspomniana nazwa rzeczna już po wybudowaniu klasztoru, upodabniając się do „nowej” nazwy wsi, także miałaby przekształcić się w formę „Oliva”. Jednak nazwa potoku w żadnej z postulowanych form (, “Oława”, „Oliva”) nie występuje w dokumentach źródłowych ${ }^{45}$.

Hipoteza, zwłaszcza po zamieszczeniu w pierwszym tomie Historii Gdańska, zdobyła niemałe uznanie wśród autorów przewodników i opracowań popularyzatorskich ${ }^{46}$. Przez historyków jest jednak odrzucana. Labuda nie znalazł odpowiedzi, w jaki sposób słowiańskie „Oława” miałoby się przekształcić w łacińskie „Oliva” ${ }^{*}$. Podobnie Błażej Śliwiński ${ }^{48}$ i Andrzej Januszajtis ${ }^{49}$. Na słabą argumentację hipotezy wskazywał Jan Wołucki ${ }^{50}$. Również w literaturze językoznawczej teoria Brockiego i Górnowicza nie zawsze jest przyjmowana jako obowiąująca: Stanisław Rospond ${ }^{51}$ i Maria Malec ${ }^{52}$ odnotowują ja tylko jako przypuszczenie.

2.

Fundamentem hipotezy językoznawców jest założenie, że u stóp Pachołka istniała osada o nazwie „*Oława”. Kiedy pod koniec XII w. przybyli w tę okolicę zakonnicy, zastana nazwa miała im na tyle się skojarzyć ze słowem „oliva” - jakoby w nawiązaniu do Góry Oliwnej - że natychmiast zaczęli używać nazwy w takiej właśnie formie. Większość dalszych rozważań językoznawców ma raczej charakter rozwinięcia tego przypuszczenia niż dowodów.

$45 \quad$ Ibidem,s. 168-169.

46 Por. E. Klamann, S. Podgórczyk, Gdańsk-Oliwa. Informator turystyczny, Gdańsk 1981, s. 3; F. Mamuszka, Oliwa. Okruchy z dziejów, zabytki, Gdańsk 1985, s. 14; E. Puzdrowski, Oliwa, „Pomerania” 1987, 5 (169), s. 13; A. Wodecka-Wyszomirska, Oliwa-Oliva. Fakty, ciekawostki, legendy. Tatsachen, Legenden, Merkwürdigkeiten, Gdańsk 1997, s. 6-8.

47 G. Labuda, Nowa synteza dziejów Gdańska średniowiecznego, „Kwartalnik Historii Kultury Materialnej” 1981, t. 29, s. 83-92.

48 B. Śliwiński, Sambor [w:] SBPN, t. 4, s. 141; idem, O rzece „Gdani” $i$ poczatkach Gdańska. Uwagi historyka do ustaleń językoznawców, „Acta Cassubiana” 2006, t. 8, s. 11-12; Kronika oliwska..., s. 11.

49 A. Januszajtis, Od Gyddanyzc do Wielkiego Gdańska, Gdańsk 2011, s. 65.

50 J. Wołucki, Gdańsk. Duńskie karty historii, Gdańsk 2000, s. 84-85.

51 S. Rospond, Stownik etymologiczny miast i gmin PRL, Ossolineum 1984, s. 88.

52 M. Malec, Stownik etymologiczny nazw geograficznych Polski, Warszawa 2003, s. 177. 
Etymologia nazwy „*Oława” - zapewne wyczerpujaca i poprawna - w żaden sposób nie wzmacnia hipotezy, skoro nadal brakuje dowodów występowania takiej nazwy w miejscu klasztoru oliwskiego. Dlatego też nie ma potrzeby, by w tym miejscu szerzej się nią zajmować.

Wątpliwość już budzi hipotetyczne skojarzenie cystersów. Nie bardzo wiadomo, dlaczego cystersi mieliby przekształcać domniemana nazwę „*Oława” w Mons Olivarum (Góra Oliwna), a nie bezpośrednio w Oliva (drzewo oliwne)?

Najpoważniejszym jednak niedostatkiem hipotezy językoznawców jest brak zrekonstruowanej nazwy „ "Oława” w jakimkolwiek (!) dokumencie źródłowym. Nie można ominąć tej słabości, argumentując, że nie znamy formy, w jakiej nazwa osady została zapisana w oryginalnym dyplomie fundacyjnym Sambora. Przywołany brak wiedzy oznacza, iż równie dobrze jak postulowana forma „*Oława” mogła w dokumencie się znaleźć forma „Oliwa”, a - ściśle rzecz biorąc - także jakakolwiek, nawet całkowicie odmienna. Tyle że za forma „Oliwa” przemawia jej występowanie w innych źródłach, a za forma „*ława” - wyłącznie przypuszczenie. Krytyczny wobec hipotezy językoznawców Wołucki słusznie zauważa, że różnica w brzmieniu nazwy wsi w oryginalnym dyplomie oraz w następnych dokumentach (także w późniejszej kopii) mogłaby stwarzać wątpliwości co do prawa własności tejże wsi, czego cystersi staraliby się uniknąć, nie mieli więc powodu do zniekształcania nazwy ${ }^{53}$.

Z kolei argument, że cystersi nie mieli nigdy nic wspólnego z Górą Oliwną w Jerozolimie, jest intrygujacy. Skoro bowiem - z tego powodu - cystersi nie mogli pierwotnie nadać nazwy „Oliva” (a tak twierdzi Górnowicz), to dlaczego mogli ją nadać po usłyszeniu domniemanej nazwy „ "Oława” za pośrednictwem skojarzenia? A co, jeśli nazwa „Oliwa” dla cystersów wcale nie miała związku z Góra Oliwna, ale właśnie - z odrzucanym a priori przez językoznawców - symbolem drzewa oliwnego? Czy wtedy cystersi mogli użyć pierwotnie takiej nazwy, czy również potrzebowaliby najpierw usłyszeć słowiańską nazwę?

Podobnie nietrafiony jest argument, że osada musiała mieć jakąś słowiańską nazwę przed przybyciem cystersów. Skoro,jakaş" nazwę - to znaczy, że mogła to być jakakolwiek nazwa, a nie, że: „„Oława”. Jeśli rzeczywiście wioska istniała.

53 J. Wołucki, Gdańsk..., s. 84. 
Śliwiński, na marginesie polemicznego artykułu poświęconego nazwie Gdańsk, zwraca uwagę, że zawarte w dokumencie fundacyjnym klasztoru określenie „loco, qui Olyva dicitur” (miejsce, które zwą Oliwa), wcale nie musi oznaczać wioski, gdyż locum to „pojęcie zaczerpnięte $\mathrm{z}$ formularza kołbackiego, a tam zawsze oznacza «klasztor»"5". Byłaby to zatem nazwa klasztoru, nie zaś wsi, która nie istniała przed fundacja opactwa ${ }^{55}$.

W odpowiedzi Błażejowi Śliwińskiemu Jerzy Treder przypomniał, że okolica późniejszego klasztoru była zamieszkana nieprzerwanie od epoki brazzu ${ }^{56}$. Fakt ten jednak wcale nie oznacza, iż dokładnie w tym miejscu, w którym powstał klasztor w drugiej połowie XII w., istniała wioska. Przecież inne wymienione $\mathrm{w}$ dokumencie fundacyjnym osady także leżą w tej samej okolicy, a nie są tożsame z Oliwa.

Dalej Treder uważa, że „nawet potencjalny błąd, inspirowany ustaleniami historyków, czyli przyjęcie istnienia tu osady przed cystersami, nie przekreśla istoty objaśnienia samej nazwy przez językoznawcę - onomastę, tj. samej możliwości ponowienia nazwy «Oława» (pierwotnie dla rzeki, obecnie Potok Oliwski) na klasztor czy osadę cysterska, czy powstała jeszcze przed nimi” ${ }^{57}$. Skoro jednak wioska nie istniała przed przybyciem cystersów, to hipoteza językoznawców potrzebuje kolejnego przypuszczenia - obok fundamentalnego o istnieniu nazwy potoku w formie „*Oława”. Należy bowiem założyć, że cystersi przybyli pod Gdańsk, usłyszeli nazwę potoku i pod wpływem skojarzeń - brzmieniowego (owej nazwy) oraz materialnego (pobliskiego wzgórza Pachołek) postanowili nazwać klasztor Górą Oliwna - Mons Olivarum, natychmiast zreszta skracając tę nazwę do formy Oliva.

Z całego szeregu wymienionych przypuszczeń można zrezygnować, stosując brzytwę Ockhama. Wystarczy uznać, że cystersi nadali zupełnie nową nazwę bez odwoływania się do zastanej (przypomnijmy: istniejącej tylko hipotetycznie). Twórcy hipotezy twierdzą że cystersi nie mogli tak postapić. Nie bardzo jednak wiadomo - dlaczego nie mogli.

Argumentację językoznawców wzmocniłyby przykłady innych upodobnień nazewniczych dokonanych przez cystersów. Szkopuł w tym, że znajdujemy przykłady raczej zaprzeczające hipotezie. Cystersi bowiem wielokrotnie nadawali swoim klasztorom zupełnie nowe

\footnotetext{
B. Śliwiński, O rzece „Gdani”..., s. 11-12, przyp. 1.

Ibidem.

J. Treder, Historyk o nazwach Gdańsk $i$ *Gdania, „Acta Cassubiana” 2007, t. 9, s. 50.

Ibidem, s. 50-51.
} 
nazwy - bez związku z nazwami zastanymi. Wcale nierzadko były to nazwy alegoryczne odwołujące się do świata symboliki religijnej ${ }^{58}$.

Na przykład mnisi z opactwa w Kołbaczu ${ }^{59}$ założyli, oprócz klasztoru oliwskiego, jeszcze dwie inne filie: w 1294 r. klasztor w Marienwalde (łac. Nemus Mariae - Las Maryi; obecnie: Bierzwnik) oraz w 1376 r. klasztor w Himmelstädt (łac. Locus Coeli - Miejsce Niebiańskie; obecnie Mironice). Cystersi zaproszeni w XIII w. do Gościkowa nie odwołali się do zastanej nazwy, ale nazwali miejsce, w którym się osiedlili - Paradisus Sanctae Mariae, czyli Raj Maryi, co uległo spolszczeniu jako Paradyż. Inny konwent cystersów, gdy w XIII w. opuszczał opactwo w Byszewie, by przenieść się w nowe miejsce, nie wykorzystał zastanej nazwy wsi Śmiewce, ale nadał nowej siedzibie nazwę alegoryczna: Corona Mariae (Korona Maryi). Stąd też późniejsza nazwa miasta: Koronowo.

Nazwy alegoryczne nadane przez zakonników nosiły również cysterskie opactwa macierzyste. Clairvaux to przecież łacińska Clara Vallis (Jasna Dolina). Taką nazwę cystersi nadali w 1115 r. dolinie wcześniej znanej jako Valle d’Absinth. Zakonnicy z Clairvaux założyli we Włoszech filie tego opactwa, nadając im identyczną nazwę Clara Vallis, która w języku włoskim przyjęła formę Chiaravalle: w 1135 r. - Chiaravalle Milanese, w 1136 r. - Chiaravalle Della Colomba i w roku 1142 - Chiaravalle di Fiastro. Druga z wielkich macierzy cysterskich to opactwo Morimond - łac. Mori Mundi (Umrzeć dla Swiata). Również ten klasztor założył włoskie filie powtarzające macierzystą nazwę - w formie: Morimondo. Powtarzały się też inne alegoryczne nazwy klasztorów - np.: Gratia Dei (Łaska Boża): La Grace-Dieu we Francji (1135), La Grace-Dieu w Burgundii (1139) czy Grace Dieu Abbey w Walii (1226). Jeden z tych klasztorów był filią założonego w 1133 r. opactwa La Charite - łac. Caritas (Miłosierdzie). W 1138 r. powstał też żeński

58 Postępowali tak zresztą nie tylko cystersi. Pomorski klasztor kartuzów został nazwany przez mnichów: Paradisus Mariae (Raj Maryi). Podobne nazewnictwo występuje w fundacjach krzyżackich: Marienburg (Miasto Maryi - Malbork), Christburg (Miasto Chrystusa - Dzierzgoń), czy Marienwerder (łac.: Insula Mariae, Wyspa Maryi - Kwidzyn).

59 Cystersi nadali nową nazwę także klasztorowi w Kołbaczu: Mera Vallis (Czysta Dolina). Ta jednak się nie przyjęła i nie zastapiła dawnej nazwy; por. L. Janauschek, Originum Cisterciensium Tomus Primus in quo praemissis congregationum domiciliis adjectisque tabulis chronologico-genealogicis veterum abbatiarum a monachis habitatarum fundationes ad fidem antiquissimorum fontium primus descripsit, Vindobonae 1877, s. 170-171; M. Franiak, Dzieje opactwa cystersów w Kołbaczu (1173-1535), Racibórz 2015, s. 84. 
klasztor o kolejnej alegorycznej nazwie: La Benisson-Dieu - łac. Benedictio Dei (Błogosławieństwo Boże).

Przykłady tego typu alegorycznych nazw można mnożyć. Przywołajmy jeszcze tylko jedną linię filiacyjna. W $1137 \mathrm{r}$. powstało opactwo L'Escaladieu - łac. Scala Dei (Schody Boga). Dla naszych rozważań ważniejsza jest filia tegoż opactwa - mianowicie klasztor La Oliva (!). Okazuje się bowiem, że nazwa Oliva (drzewo oliwne) wcale nie była niespotykana wśród cysterskich klasztorów. Pojawiła się kilkadziesiąt lat przed założeniem pomorskiego klasztoru, bo w 1134 r., gdy król Nawarry Garcia Ramirez ufundował klasztor w pobliżu Carcastillo, nazwany został La Oliva - łac. Oliva ${ }^{60}$. Opactwo istniało do 1835 r., a w 1927 r. zostało ponownie zasiedlone - przez trapistów.

Oprócz nawarskiego opactwa istniał też żeński klasztor cysterski Notre Dame de l'Olive, a krócej L'Olive (znowu łac. Oliva), założony w 1220 r. (1240?) w diecezji Cambray, w Brabancji (obecnie Belgia, prowincja Hainaut, gmina Morlanwelz) ${ }^{61}$.

Zbliżone nazwy nosiły jeszcze dwa klasztory cysterskie we Francji. Pierwszy to męski klasztor L'Olivet (Notre-Dame d'Olivet), łac. Olivetum (to raczej: Ogród Oliwny), w diecezji Bourges we Francji (obecnie: departament Loir-et-Cher w Regionie Centralnym, gmina Saint-Julien-sur-Cher ${ }^{62}$. Klasztor ten został założony w 1144 (1145?) r. przez Étienne'a de Graçay jako filia francuskiego opactwa La Cour-Dieu (łac. Curia Dei - kolejna alegoryczna nazwa klasztoru cysterskiego) i istniał do 1791 r. Drugi to żeński klasztor Les Olives (Sainte Marie des Olieux, Les Olieux del Lec). Powstał w 1204 r. na posiadłości Les Monges koło Narbonne, podarowanej przez kupca Jeana Bistan ${ }^{63}$.

Skoro cystersi użyli nazwy „Oliva” (i podobnych) dla klasztorów w innych miejscach, czemu nie mogli jej użyć na Pomorzu? Pojawia się też inna kwestia. Czy nazwa klasztoru oliwskiego ma związek z Góra Oliwną (w wersji Górnowicza i Brockiego miałby być to związek wtórny, ale jednak istotny), czy skoro łacińskie słowo oliva oznacza po prostu drzewo oliwne, w tym symbolu należy szukać etymologii? Czy istniały jakieś głębsze powody, by nazwa klasztoru miała odniesienie alegoryczne do Góry Oliwnej czy drzewka oliwnego? Jeśli bowiem istniały,

\footnotetext{
60 Por. L. Janauschek, Originum Cisterciensium..., s. 119.

61 O. Hubinont, Monographie Historique de l'Abbaye de l'Olive, Morlanwelz 1897.

62 Dictionnaire des abbayes et monasteres, Paris 1856, s. 601; L. Janauschek, Originum Cisterciensium..., s. 81.

63 Dictionnaire des abbayes..., s. 600; C.H. Berman, The cistercian evolution: the invention of a religious order in twelfth-century Europe, Pennsylvania 2010, s. 133.
} 
to niesłusznie językoznawcy a priori zakładają nienaukowość etymologii wiążących z tym symbolem nazwę podgdańskiej Oliwy, a przede wszystkim niesłusznie zakładaja, że nazwa „Oliva” nie mogła być pierwotną nazwą nadaną przez cystersów.

\section{Symbolika Góry Oliwnej i drzewa oliwnego}

Powyższe rozważania miały przede wszystkim na celu wskazanie, jak kruche sa podstawy, na których została zbudowana hipoteza polskich językoznawców. Hydronimiczna etymologia jest oparta na hipotetycznych założeniach niemających potwierdzenia w źródłach, a wspieranych kolejnymi przypuszczeniami. Przeczą tej hipotezie zwyczaje cysterskie nadawania klasztorom nazw alegorycznych. Twórcy teorii hydronimicznej odrzucają a priori alegoryczne pochodzenie nazwy klasztoru, najwyraźniej ignorując zwyczaje zakonu. Notabene alegoryczna etymologia nazwy klasztoru właściwie przez nikogo innego nie została zanegowana. Wydaje się zatem, że trzeba by się zatrzymać nad biblijnymi symbolami Góry Oliwnej i drzewka oliwnego i poszukać znaczeń, jakie mogły one nieść dla mnichów zakonu cysterskiego, gdy zakładali pod Gdańskiem nowy klasztor.

Wzmianki o Górze Oliwnej wznoszącej się na wschód od Jerozolimy pojawiają się w Biblii kilkakrotnie.

Na Górze Oliwnej zatrzymuje się król Dawid uciekajacy z Jerozolimy przed zbuntowanym synem Absalomem. Opuszczajac stolicę, zabiera ze sobą Arkę Przymierza, ale na zboczu góry uznaje, że miejsce Arki jest w mieście (2 Sm 15,30nn.). Może do tej sceny nawiązuje wizja z Księgi Ezechiela. Jej autor, nie wymieniając wprawdzie nazwy, mówi o górze położonej na wschód od Jerozolimy, na której zatrzymuje się Chwała Pańska opuszczająca Jerozolimę (Ez 11,23). Inna wizja związana z górą pojawia się w Księdze Zachariasza. W dniach ostatecznych Bóg występujacy do walki „dotknie stopami Góry Oliwnej”, a ta „rozstapi się w połowie od wschodu ku zachodowi i powstanie wielka dolina" (Za 14,4).

W Nowym Testamencie Góra Oliwna jest powiązana przede wszystkim z wydarzeniami z ostatnich dni życia Jezusa. Jest świadkiem „triumfalnego wjazdu”, gdy Jezus przemierza na osiołku drogę z Betanii do Jerozolimy - przez Górę Oliwną (Mt 21,9).

Niższy stok góry to Getsemani - dosłownie „tłocznia oliwy” - tradycyjnie tłumaczone jako Ogród Oliwny lub Ogrójec. W tym miejscu Jezus spotykał się z uczniami, medytował i modlił się przed aresztowaniem 
(Mt 24,3; Łk 21,37; Mt 26,30). I wtedy - wyprzedzajac dalsze rozważania o symbolu drzewa oliwnego - pot i krew Jezusa miały namaścić korzenie rosnacych w ogrodzie oliwek.

$\mathrm{Na}$ Górze Oliwnej miało wydarzyć się wniebowstapienie Jezusa (Dz 1,12). Tradycyjnie też górę uważa się za miejsce, gdzie Jezus nauczył Apostołów modlitwy „Ojcze nasz”. To tu miała zostać złożona do grobu Maria Panna, a zatem miałoby się dokonać Wniebowzięcie Maryi ${ }^{64}$.

Wydarzenia biblijne usytuowane na Górze Oliwnej i w Ogrodzie Oliwnym to częste motywy w sztuce sakralnej. Na samym wzniesieniu już w starożytności powstawały sanktuaria chrześcijańskie upamiętniające wspomniane wydarzenia.

Symbole Góry Oliwnej i drzewa oliwnego nakładają się na siebie. To przecież od rosnących tu oliwek (wyciętych przez Tytusa podczas powstania żydowskiego) pochodzi nazwa wzniesienia. Symbol drzewa niesie jednak kolejne znaczenia

Chyba bardziej sa znane symboliczne treści kojarzone nie tyle z drzewem, co z gałązką oliwną oraz wyciśniętą z owoców oliwa. Pojawiający się w Biblii obraz namaszczenia oliwą to symbol sakralizacji, błogosławieństwa, wyróżnienia i uzdrowienia. W Starym Testamencie namaszczani oliwą byli królowie, kapłani i prorocy, a najważniejszym pomazańcem miał być Zbawiciel (hebr.: Mesziah - Mesjasz - Pomazaniec Jahwe i grec.: Xpıotós - Christos - Namaszczony). Symbolikę tę przejął Nowy Testament. Zwyczaj namaszczania oliwą znalazł miejsce w liturgii Kościoła - zwłaszcza w liturgii sakramentów ${ }^{65}$.

Z kręgu symboliki biblijnej pochodzi wizerunek gołębicy przynoszącej listek czy gałązkę oliwną w dziobie po opadnięciu wód potopu $(\operatorname{Rdz} 8,11)^{66}$. Gałązka oliwna jest atrybutem posłańca ${ }^{67}$ i kojarzy się powszechnie z pokojem i pojednaniem - motyw gałązek drzewa oliwnego jako zapowiedzi pokoju występował również w symbolice antycznej ${ }^{68}$.

64 Więcej o symbolu Góry Oliwnej zob. B.D. Metzger, M.D. Coogan, Stownik wiedzy biblijnej, konsult. wyd. pol. W. Chrostowski, Warszawa 1992, s. 201; R. Rubinkiewicz, Góra Oliwna [w:] Encyklopedia katolicka, t. 5, red. J. Bieńkowski, Lublin 1989, s. 1372-1373.

65 M. Lurker, Stownik obrazów i symboli biblijnych, Poznań 1989, s. 156-157; X. Leon-Dufour, Stownik Nowego Testamentu, Poznań 1986, s. 412-413; D. Forstner, Świat symboliki chrześcijańskiej. Leksykon, Warszawa 2001, s. 171-174.

66 J. Małocha, Symbolika roślin w sztuce wczesnochrześcijańskiej [w:] Symbolika roślin. Heraldyka i symbolika chrześcijańska, red. J. Marecki i L. Rotter, Kraków 2007, s. 63-71.

67 P. Kowalski, Leksykon - znaki świata. Omen, przesad, znaczenie, Wrocław 1998, s. 392.

68 Podręczna encyklopedya kościelna..., s. 193; M. Lurker, Stownik..., s. 158-159; W. Kopaliński, Stownik mitów i tradycji kultury, Warszawa 1987, s. 789; D. Forstner, 
Do tego ostatniego znaczenia odwołano się, upamiętniając podpisany w 1660 r. traktat pokojowy zwany pokojem oliwskim. W dawnej bibliotece klasztornej (tzw. Sala Pokoju Oliwskiego) powstało malowidło sławiące podpisanie pokoju: na obrazie została przedstawiona między innymi gołębica z gałązka oliwną w dziobie ${ }^{69}$. To jednak o wiele późniejsze skojarzenia, choć przez swoje współbrzmienie z nazwą klasztoru wielokrotnie przywoływane.

Wiecznie zielone drzewo oliwne jest nośnikiem kolejnych treści symbolicznych. W Starym Testamencie oznacza Naród Wybrany. Księga Ozeasza mówi o Izraelu, że „rozwiną się jego latorośle, będzie wspaniały jak drzewo oliwne" (Oz 14,7). Księga Jeremiasza nazywa naród wybrany Oblubienica Boga, o której sam Stwórca mówi, że jest „zielonym drzewem oliwnym, zdobnym pięknymi owocami” (Jer 11,16).

Drzewo oliwne oznacza również człowieka sprawiedliwego. Tak owocodajne drzewo oliwne z Psalmu 51 interpretował Orygenes ${ }^{70}$. Tomasz z Akwinu uważał je za symbol wyznawców ${ }^{71}$.

Oliwka jest symbolem błogosławieństwa Bożego i wiecznej mądrości - w Księdze Syracha Mądrość Boża mówi, że wyrosła jak piękne rośliny, a wśród nich ,jak wspaniała oliwka na równinie” (Syr 24,14) ${ }^{72}$.

$\mathrm{Z}$ drewna oliwki zbudowane były odrzwia świątyni Salomona (1 Krl 6,32-33). Z pnia oliwki miał też powstać krzyż Jezusa, a przynajmniej jedna z jego belek - to jednak już późniejsza tradycja, tylko wywiedziona z symbolu oliwki ${ }^{73}$.

W Nowym Testamencie pojawia się, nawiąujący do starotestamentalnych symboli, obraz gałązek dzikiej oliwki wszczepionych w pień szlachetnego drzewa ( $\mathrm{Rz} 11,11-24)$, co wprawdzie jest niezgodne z praktyką ogrodnicza, ale celnie obrazuje chrześcijan pochodzenia żydowskiego (pień szlachetnej oliwki) i pochodzenia pogańskiego (gałązki dzikiej oliwki). Inny obraz dwóch drzew oliwnych symbolizujących prorokujących wybrańców Boga pojawia się zarówno w Starym, jak i Nowym Testamencie (Za 4,11; Ap 11,3-4).

Świat symboliki..., s. 171-174; S. Kobielus, Florarium christianum. Symbolika roślin - chrześcijańska starożytność i średniowiecze, Kraków 2006, s. 151.

69 Zob. A. Szpakiewicz, Klasztor pocysterski w Oliwie. Przewodnik po dawnych wnętrzach klauzurowych, wyd. 3, Gdańsk 2011, s. 62-63.

$70 \quad$ Za: S. Kobielus, Florarium christianum..., s. 154.

71 Divi Thomae Aquinatis Doctoris Angelici sermones pii admodum et docti, Widmanstadt 1744, s. 127.

72 Zob. Z. Włodarczyk, Symbolika roślin..., s. 169-180.

73 Zob. S. Kobielus, Florarium christianum..., s. 151. 
W epoce starożytnego chrześcijaństwa i w średniowieczu symbol drzewa oliwnego był odnoszony do Marii Panny. Obraz ten przywołało wielu spośród ojców Kościoła - między innymi Jan Chryzostom (zm. 407), Jan Damasceński (zm. około 749), a później za nim św. Bonawentura (ok. 1217-1274) ${ }^{74}$. Benedyktyn Piotr Cellensis (1115-1183) w hymnie do Maryi pisał: „Tu oliva speciosa, portans nobis pacis ramum"75. Wielki opat cysterski Bernard z Clairvaux (1090-1153) nazywa Maryje oliwką owocodajna („oliva fructifera”), przeciwstawiajac ja pramatce Ewie - bezpłodnej wierzbie (,salix infructuosa") ${ }^{76}$. Podobnie inny cysters Adam Perseniusz (1145-1221) odnosi do Maryi określenia „oliva speciosa” i „oliva fructifera”77. Taka interpretacja symbolu oliwki jest o tyle istotna w naszych rozważaniach, że Maria Panna była patronką wszystkich klasztorów cysterskich.

W kontekście rozważań o nazwie klasztoru ważne jest również, że określenie „oliva fructifera” pochodzi z wersetu biblijnego psalmu przywoływanego przez zakonników klasztoru oliwskiego. Werset „ego autem sicut oliva fructifera in domo Dei" umieszczony został m.in. na epitafium pierwszego oliwskiego opata Ditharda (1186?-1189?) obok wizerunku drzewa oliwnego. W psalmie, z którego pochodzi cytat, oliwka staje się symbolem zaufania Bogu i wzrostu na chwałę Stwórcy. Symbol taki doskonale komponuje się z obrazem „zasadzonego” na chwałę Bożą klasztoru, którego zakonni synowie sa - tu cytat z innego psalmu - ,jak gałązki oliwne wokół stołu Pańskiego" (Ps 128(127), 3). Owszem, wizerunki te powstały kilka stuleci po powstaniu klasztoru, ale Psalm 51 znalazł szczególne miejsce w liturgii cysterskiego oficjum jeszcze w XII w.

Od starożytności kształtował się zwyczaj odmawiania modlitw obejmujących cały psałterz i wiele czytań biblijnych oraz fragmentów kazań i pism składających się na Tradycję Kościoła. Wzbogacana hymnami, responsoriami i antyfonami, rozłożona cyklicznie w ciagu każdego dnia wspólna modlitwa chorałowa - „Divinum Officium” - przekształciła się później w brewiarz, którego odmawianie jest obowiązkowe dla każdego kapłana i zakonnika ${ }^{78}$.

74 Zob. zestawienie takiej interpretacji symbolu drzewa oliwnego w pismach Ojców Kościoła: H. Marriacus, Polyanthea Mariana..., 1684, s. 85-87.

75 Za: S. Kobielus, Florarium christianum..., s. 153.

76 Zob. ibidem, s. 152, przyp. 2.

77 Ibidem, s. 153.

78 Więcej o kształtowaniu liturgii godzin w średniowieczu zob. J. Bisztyga, Officium divinum od IV do XIII wieku, „Liturgia Sacra. Liturgia - Musica - Ars” 2014, t. 20/2 (44), s. 303-333. 
Zakonnicy spotykali się kilka razy w ciagu dnia i nocy, odmawiając przypisane na każdy dzień roku liturgicznego modlitwy. Psalm 51 powtarzali w całości przynajmniej raz w cyklu miesięcznym. Jego fragment mówiący o owocodajnej oliwce pojawiał się w formie responsoriów w dniu Ofiarowania Najświętszej Marii Panny (obchodzonego 21 listopada), ale też przy okazji wspomnienia św. Bernarda z Clairvaux, uważanego za współtwórcę zakonu cysterskiego. Kanonizacja Bernarda miała miejsce w 1174 r. i z pewnością było to wielkie wydarzenie dla całego zakonu. Wraz z kanonizacją powstało oficjum $\mathrm{w}$ dniu jego liturgicznego wspomnienia (20 sierpnia). Zamieszczono w nim teksty z pism samego Bernarda z Clairvaux. W jego dorobku pisarskim znalazło się kazanie wygłoszone na pogrzebie biskupa Malachiasza z Armagh (1094-1154; kanonizowany w 1190) ${ }^{79}$. Kazanie to weszło później w skład czytań brewiarzowych w dniu wspomnienia św. Malachiasza, ale jego fragment przywołujący symbol drzewa oliwnego z Psalmu 51 pojawił się też $\mathrm{w}$ formie responsorium w godzinie „matutinum” otwierającej oficjum wspomnienia św. Bernarda ${ }^{80}$. Inny fragment, także wspominajaccy drzewo oliwne, cytowany jest w antyfonie tegoż oficjum ${ }^{81}$. Wszyscy mnisi zakonu cysterskiego, czcząc rokrocznie dzień pamięci swojego wielkiego świętego i twórcy wielkości zakonu (bo tak odbierany jest Bernard z Clairvaux), śpiewali modlitwy autorstwa św. Bernarda przywołujace symbol drzewa oliwnego.

Nie wiemy, kiedy dokładnie cystersi podjęli się utworzenia klasztoru w okolicach Gdańska. Rok 1186, w którym konwent obją klasztor, stanowił domknięcie procesu fundacji trwajacej może od znanej z dokumentu Sambora daty 1178. Daty te mieściły się w okresie żywej pamięci o kanonizacji Bernarda, a nawet pewnego uniesienia w zakonie. Można tak sądzić na przykładach kanonizacji wielkich postaci, również współcześnie. Zapewne nie uda się rozstrzygnąć jednoznacznie, jakimi motywami kierowali się zakonnicy, obdarzając

79 Sancti Bernardi abbatis Clarae-Vallensis opera omnia..., ed. J. Mabillon, t. 1, Paris 1839, s. 1500-1502.

80 „O oliva fructifera in domo dei oleum laetitiae fovens beneficiis coruscans miraculis fac nos ejus qua frueris lucis suavitatisque participes ", za: Cantus index online catalogue for mass and office chants, http://cantusindex.org (dostęp: 25.03.2019). Responsorium zachowało się w kilku manuskryptach, w tym w antyfonarzu z opactwa w Lubiążu, zob. Antiphonarium de tempore et de sanctis per annum, IF 401, rękopis zdigitalizowany: http://www.bibliotekacyfrowa.pl/publication/15651 (dostęp: 25.03.2019).

81 „Quasi oliva pullulans et cypressus in altitudine se tollens sic vir beatus ad gloriam sanctitatis ascendita”, za: Cantus index online catalogue for mass and office chants, http://cantusindex.org (dostęp: 25.03.2019). 
nowy klasztor mianem „Oliva”. Choć akurat teza o zniekształceniu zastanej słowiańskiej nazwy nie wydaje się do obronienia. Rozstrzygnięcie, czy cystersi, osiedlając się pod Gdańskiem, chcieli przywołać symbol Góry Oliwnej, czy raczej drzewa oliwnego, z pewnościa wymaga dalszych badań. Jeśli jednak uwzględnić treści, jakie niesie ze sobą symbol drzewa oliwnego, miejsce tego symbolu w modlitwie chorałowej, jego powiąania z postaciami Marii Panny oraz Bernarda z Clairvaux, a także fakt, że klasztor oliwski jest poświęcony właśnie Marii Pannie (jak wszystkie klasztory cysterskie) oraz św. Bernardowi z Clairvaux, to wiele przemawia za tym, że cystersi już na etapie decydowania o fundacji mogli planować uczczenie swojego wielkiego świętego, a oddając nowy klasztor pod patronat św. Bernarda, mieli wiele powodów, by niejako we współbrzmieniu z tym patronatem obdarzyć klasztor mianem oliwki owocodajnej - symbolu tak mocno związanego z postacią Bernarda z Clairvaux.

\author{
Abstract \\ "Oliwa" - the provenance of the name of the Cistercian \\ monastery near Gdańsk: A research contribution
}

At the end of the $12^{\text {th }}$ century, the regent of Pomerelia Sambor I founded a Cistercian monastery near Gdańsk. The monks, who came there from their home monastery in Kołbacz, called the new monastery "Oliva". In the Cistercian tradition, this name referred to the Biblical symbol of the olive tree. Historians favour an allegorical etymology of the monastery's name, but some scholars attempt to link it to the symbol of the Mount of Olives. In the $20^{\text {th }}$ century Polish linguists put forth a hypothesis about the Slavic provenance of the monastery's name. Reconstructed as "* Oława", it was supposed to be a river name. According to this hypothesis, the name "Oliva" is supposed to have resulted from the Cistercians changing the original name due to a phonetic association with the Mount of Olives ("Montes Olivarum"). However, not only the absence of the supposed original name in the source texts speaks against this hypothesis, but also the Cistercian custom of giving monasteries completely new names, often allegorical. The authors of the hypothesis also completely disregarded the meanings the Cistercians were giving to Biblical symbols. What is especially important in this case is the relation between the olive tree and the monastery's patrons: the Blessed Virgin and Saint Bernard of Clairvaux. 